\section{Preferences on Vital and Nonvital Tooth Bleaching: A Survey Among Dentists from a City of Southern Brazil}

Flávio Fernando Demarco ${ }^{1}$, Marcus Cristian Muniz Conde ${ }^{1}$, Caroline Ely ${ }^{1}$, Eliana Nascimento Torre ${ }^{1}$, José Ricardo Souza Costa ${ }^{1}$, María Raquel Fernández ${ }^{1}$, Sandra Beatriz Chaves Tarquinio ${ }^{2}$
'Department of Restorative Dentistry, UFPel - Federal University of Pelotas, Pelotas, RS, Brazil ${ }^{2}$ Department of Semiology and Clinics, UFPel - Federal University of Pelotas, Pelotas, RS, Brazil

Correspondence: Prof. Dr. Flávio Fernando Demarco, Rua Gonçalves Chaves, 457, 96015-560 Pelotas, RS, Brasil. Tel: +55-53-3222-4439 R.136. e-mail: flavio.demarco@ pq.cnpq.br/ffdemarco@gmail.com

Key Words: tooth bleaching, dentist, carbamide peroxide, hydrogen peroxide.

\section{Introduction}

Bleaching treatments have become very popular with the increasing demand for esthetics in practically all fields of everyday life (1). Vital tooth bleaching can be performed externally in vital teeth, using at-home or in-office techniques, or both techniques in combination (1). Nonvital bleaching for a root-filled tooth is carried out intracoronally or using a combination of external and internal procedures (2). Several products and different techniques are available for tooth bleaching, with most variations relating to concentration and type of peroxide releasing agents (2). Basically, the mechanism of action of bleaching agents is similar. Peroxide-containing agents break down into water and oxygen, which diffuses through the dental structure, causing oxidation and reduction of organic pigments that are located mainly within the dentin structure, ultimately producing the whitening effect (3).

While nonvital tooth bleaching is performed at the dental office using strong peroxide agents, such as high concentration hydrogen peroxide (HP) or hydrogen peroxide-releasing agents (carbamide peroxide - CP and sodium perborate - SP) (2), vital tooth bleaching can be performed with high concentration (in-office) or low concentration agents (at-home bleaching or over-thecounter - OTC - products) $(1,3,4)$. Agent concentration and technique have been claimed to influence the bleaching outcome $(2,5)$.

Some adverse effects are reported on vital tooth bleaching, including tooth sensitivity, gingival irritation, reduced adhesion to dental tissues and alterations in the dental structure (3-5). In nonvital bleaching, the occurrence of external root resorption, morphological alterations in dental tissues, alteration of dental materials' properties and decrease of tooth resistance and adhesion have also been reported $(2,6,7)$.

Dentist's knowledge and clinical practices regarding different dental treatments have been investigated (8-10), but only one study has evaluated the choice of dentists regarding bleaching agents for nonvital and vital treatments (11). This questionnaire-based survey assessed the preferred techniques and products to perform nonvital and vital dental bleaching by a population of dentists from the southern region of Brazil. It was also investigated whether their options could be influenced by their time in clinical practice and the level of specialization (post-graduate training). 


\section{Material and Methods}

This cross-sectional study was performed during a 4-month period in Pelotas, a medium-sized city in the southern region of Brazil with a strong dental community. All dentists registered $(n=276)$ at the Regional Council of Dentistry (C.R.O. - Portuguese acronym), Pelotas Division, were invited to participate in the study. Data were collected through a self-applied questionnaire with closed questions. The variables comprised sociodemographic information (gender and skin color), professional characteristics (graduation time and level of specialization), attitudes and knowledge of different restorative procedures. The Ethics Committee of the Federal University of Pelotas approved the research protocol under registration number 116/2009.

The time since graduation was collected in a continuous level and then assigned to three groups: $\leq 10$ years, $11-20$ years and $>20$ years. Continuous education information was dichotomized. Specialists were considered those attending a formal post-graduation course (specialization, Master's or $\mathrm{PhD}$ degree), while non-specialists were those with a DDS degree only (general dentist). Three questions concerning bleaching procedures specifically were presented to the participants. The first and second questions referred to s vital tooth bleaching: 1) "What is your favorite protocol to bleach vital teeth?", with two possible answers: a) athome; b) in-office; and 2) "What is your first choice to bleach discolored vital teeth?", with the following possible answers: a) 10\% carbamide peroxide (CP); b) 15 to 22\% CP; c) $>30 \% \mathrm{CP} ; \mathrm{d}$ ) $>30 \%$ hydrogen peroxide (HP) or e) overthe-counter (OTC) products. The third question referred to nonvital tooth bleaching: "What is your first choice to bleach discolored nonvital teeth?" with the possible answers: a) 10\% CP; b) 15 to 22\% CP; c) high concentration $(>30 \%) \mathrm{CP} ; \mathrm{d}$ ) high concentration (>30\%) HP; e) sodium perborate (SP) + water/or HP.

The questionnaires were personally delivered to each dentist's office and were collected 1 week later together with the signed informed consent form. Loss of participants was considered when professionals did not return the questionnaire/informed consent form after two visits. The questionnaire was pre-tested with professionals not involved in the study.

Data were submitted to descriptive analyses and the association between vital or nonvital tooth bleaching with independent variables (time since graduation and post-graduation training) was tested with chi-square or Fisher's exact test. The analyses were carried out with Stata 10.0 software (StataCorp, College Station, TX, USA). A significance level of $\alpha=0.05$ was set for the study.

\section{Results}

From the total of dentists registered at the CRO-Pelotas
Division, who were visited and received the questionnaire, 187 (68\%) effectively participated in the study. The losses were mainly related to lack of retuning the questionnaire or signing the informed consent, but there were also some refusals. As the questionnaire was self-applied, some of the dentists missed some questions and so the number of answers varied for each question.

Descriptive analysis (Table 1 ) showed that $52.4 \%$ of the dentists were females, $96 \%$ classified themselves as White, time since graduation $\geq 10$ years $(53.2 \%)$ was the most frequent and $64.7 \%$ of the dentists had some kind of post-graduation training.

At-home bleaching therapy was broadly preferred (78.1\%) over in-office (21.9\%) bleaching. Asked about the first-choice material to perform at-home bleaching,

Table 1. Descriptive analyses of the studied variables among dentists $(n=187)$. Pelotas, RS, Brazil, 2009.

\begin{tabular}{|c|c|c|}
\hline Variables & $N=187$ & $\%(1 C$ 95\%) \\
\hline \multicolumn{3}{|l|}{ Gender } \\
\hline Male & 89 & $47.6(40.3-55.0)$ \\
\hline Female & 98 & $52.4(45.0-59.7)$ \\
\hline \multicolumn{3}{|c|}{ Time since graduation (years)* } \\
\hline$\geq 10$ & 84 & $45.4(38.2-52.9)$ \\
\hline $11-20$ & 43 & $23.2(17.2-29.7)$ \\
\hline$\leq 30$ & 58 & $31.3(10.7-21,5)$ \\
\hline \multicolumn{3}{|c|}{ Post-graduation training* } \\
\hline None & 66 & $36.3(29.5-43.7)$ \\
\hline Yes & 116 & $63.7(56.3-70.5)$ \\
\hline \multicolumn{3}{|c|}{ Type of bleaching (vital teeth)* } \\
\hline At-home & 114 & $78.1(71.5-83.8)$ \\
\hline ln-office & 32 & $21.9(16.2-28.5)$ \\
\hline \multicolumn{3}{|l|}{ Vital Bleaching* } \\
\hline CP $10 \%$ & 63 & $40.9(33.5-48.1)$ \\
\hline CP $15-22 \%$ & 51 & $33.1(26.5-40.4)$ \\
\hline $\mathrm{CP}>30 \%$ & 14 & $9.1(5.4-14.2)$ \\
\hline $\mathrm{HP}>30 \%$ & 18 & $11.7(7.5-17.3)$ \\
\hline OTC products & 8 & $5.2(2.6-9.6)$ \\
\hline \multicolumn{3}{|l|}{ Nonvital Bleaching* } \\
\hline CP $10 \%-22 \%$ & 15 & $10.3(6.2-15.4)$ \\
\hline $\mathrm{CP}>30 \%$ & 40 & $27.6(21.5-34.8)$ \\
\hline $\mathrm{HP}>30 \%$ & 46 & $31.7(25.0-38.7)$ \\
\hline $\mathrm{SP}+$ water or HP & 44 & $30.4(24.0-37.6)$ \\
\hline
\end{tabular}

*Number of valid answers. 
$40.2 \%$ of the surveyed dentists chose 10\% CP. Regarding the material for non-vital therapies there were similar response rates for 3 techniques: $31.7 \%$ of respondents chose the $>30 \% \mathrm{HP}$, followed by SP (30.4\%) and $>30 \%$ CP (27.6\%). Table 2 shows a strong association between post-graduation training and type of vital bleaching agent chosen by dentists $(p=0.003)$. Dentists with postgraduation training indicated more frequently at-home bleaching techniques when compared with those without this training.

A correlation was found between time since graduation and type of vital bleaching therapy $(p=0.039)$. Younger professionals indicated home bleaching therapies more frequently. For nonvital bleaching therapies, dentists' choice for one or another product was not associated with time since graduation $(\mathrm{p}=0.532)$ or post-graduation training $(p=0.083)$.

Table 2. Association between choice of the vital bleaching technique (at-home or in-office) and the independent variables

\begin{tabular}{lrrr}
\hline \multirow{2}{*}{ Variable/Category } & \multicolumn{2}{c}{ Vital bleaching technique } & \multirow{2}{*}{ p value } \\
\cline { 2 - 3 } & At-home & ln-office & \\
\hline Time since graduation (years) & & & 0.039 \\
$\leq 10$ & $65(81.2)$ & $15(18.8)$ & \\
$11-20$ & $24(82.8)$ & $5(17.2)$ & \\
$21-30$ & $15(75.0)$ & $5(25.0)$ & \\
$>30$ & $8(53.3)$ & $7(46.7)$ & \\
Post-graduation training & & & 0.003 \\
No & $36(64.29)$ & $20(35.71)$ & \\
Yes & $73(85.88)$ & $12(14.12)$ & \\
\hline
\end{tabular}

\section{Discussion}

In this study, at-home bleaching was broadly preferred (78.1\%) for vital tooth bleaching therapy compared with in-office therapies (21.9\%). The literature suggests that at-home bleaching therapies are safer than in-office due to the lower peroxide concentration $(5,12)$. At-home and in-office bleaching therapies has been shown to have similar bleaching efficacy (13). A previous study showed no significant difference between bleaching efficacy when the home bleaching technique was performed alone or combined with in-office treatment (4). There is also a tendency for increased tooth sensitivity when high concentration agents are used $(5,25,14)$.

The agent $10 \% \mathrm{CP}$ was the preferred bleaching material for vital tooth bleaching $(40.9 \%)$. This finding is consistent with the literature that indicates the use of $\mathrm{CP}$ at low concentrations as the most popular material for at-home bleaching techniques $(15,16)$. In fact, dentist-supervised tooth bleaching using 10\% CP gel with custom-made trays is still considered the gold-standard treatment for tooth discoloration $(5,15,16)$ and it is the only agent concentration accepted by the American Dental Association (ADA) for at-home bleaching (17). The main advantages of this technique are the ease of use, shorter chairtime and low incidence of tooth sensitivity and gingival irritation $(3,5,18)$. Over $30 \%$ of the surveyed dentists answered to use CP at concentrations above 10\%, which could be related to the assumption that increasing the bleaching agent concentration would enhance the whitening effect as there would be more oxygen release allowing a stronger and faster outcome $(3,5)$. However, clinical trials have demonstrated that increasing the bleaching agent concentration did not improve significantly the whitening effect $(18,19)$. Furthermore, it is important to point out that concerns related to the potential deleterious effect on the pulp tissue could be observed with higher concentration bleaching gels in vital tooth bleaching (12). Only 5\% of the participants indicated OTC products as the first choice to treat discolored vital tooth bleaching. Indeed, it has been demonstrated that the only OTC products with bleaching efficacy are the whitening strips $(1,15)$. The other OTC products present some whitening effect, but without clinical relevance (20).

For nonvital tooth bleaching, three different techniques had similar preferences among respondents (27.4$31.7 \%)$. The first selected agent was $>30 \%$ HP (31.7\%). The main reason 
for such choice could be related to the long time that this bleaching agent has been available to treat nonvital discolored teeth (more than 60 years) (2). In addition, bleaching treatment with high concentration HP agents has provided good clinical results (21). However, a side effect related to high concentration HP products is the potential occurrence of external root resorption $(2,6)$, making the dentists more cautious with their use. External root resorption is related to the penetration of bleaching agents into the dentinal tubules at the cementoenamel junction, producing an immunological response in the periodontal tissues (6). It has been shown that high HP concentrations alter dramatically the structural and biochemical properties of dental hard and soft pulp tissue (22). The use of SP (+ water or HP) inside the pulp chamber in the walking bleach technique may reduce the chance of external root resorption because SP is less caustic and releases a less amount of ions. This technique also shows comparable results to those of $>30 \% \mathrm{HP}$ and a heat source (23). More recently, higher concentration $\mathrm{CP}$ gels have been launched to the market with indication to treat nonvital discolored teeth and became more popular than HP products. A possible explanation could be the greater availability of ¿ CP products. In addition, potential side effects related to high concentration HP agents, such as external root resorption (24), are minimized because of the lower final amount of ions released from CP products. As a higher HP concentration is desirable for nonvital tooth bleaching, a large number of participants of this survey did not selected $\mathrm{CP}$ at low concentrations. Nevertheless, some in vitro results disclosed that even these lower concentrations would be able to bleach discolored nonvital teeth (23).

In relation to vital tooth bleaching, post-graduation training and time of clinical activity affected the choice. In continuous education, the preference for at-home bleaching by specialized professionals incorporates a greater critical sense and scientific knowledge deriving from a closer contact with the scientific literature. Indeed, at-home bleaching therapies are as effective as in-office therapies, but have fewer adverse effects (4). The literature clearly shows that the level of continuous education influences significantly dentist's attitudes and knowledge of dental procedures. In this context, there is a trend towards specialists indicating more frequently research evidencebased treatments (25). It is likely that in the present study the dentists with post-graduation training indicated more frequently at-home bleaching therapies because these dentists are updated about the safety and efficacy of this type of treatment.

On the other hand, an at-home bleaching therapy was more often indicated by professionals with less time of clinical activity than by more experienced professionals.
One possible explanation may be that at home bleaching treatments appeared in the literature in the last 20 years $(1,2)$, and therefore dentists who graduated in the last 20 years are more likely to have been taught this technique during school time. Dental students being more educated on bleaching techniques during the undergraduate period are more confident and more inclined to perform bleaching treatments in their professional clinical practice (11).

It was also observed that time since graduation and specialization level did not influence the choice of nonvital tooth bleaching technique. This lack of association may be due mainly to the well-established standards for bleaching of discolored pulpless teeth $(2,21,24)$. Although the association was not statistically significant, it was observed that a larger number of professionals chose the $\mathrm{CP}$ at low or high concentration. These choices may be related to the concern about potential adverse effects of $\mathrm{HP}$, and also because $\mathrm{CP}$ appeared more recently on the market in comparison with HP and SP.

This study presents some limitations that should be highlighted. It was a survey directed to dentists based on a questionnaire comprising questions related to different restorative treatments and therefore there was limitation to include more questions related to bleaching treatments. However, this study is the first one to investigate dentists' preferences regarding bleaching therapies for vital or nonvital teeth. The use of questionnaires is an important tool to collect information in a relatively short period of time (8-10). A self-applied questionnaire with closed questions was used in this study, which is easy to apply and the dentists could answer them without alterations in their daily clinical routine. Nevertheless, another visit was needed to recollect the questionnaire, which was more time-consuming, and some of the questions remained without answers (10). The response rate in the present study was $68 \%$, which is acceptable and higher compared with other surveys $(8,9)$.

In conclusion, the results of this study demonstrated that at-home bleaching was broadly preferred over in-office bleaching for vital teeth. The 10\% CP gel was preferred for vital tooth bleaching, while high concentration $\mathrm{HP}$ was the most used agent for nonvital tooth bleaching technique. Time of clinical practice and post-graduation training influenced the choices for vital tooth bleaching treatments.

\section{Resumo}

Este estudo avaliou as preferências de cirurgiões-dentistas sobre o clareamento de dentes vitais e não-vitais. Também investigou a possivel relação entre o grau de formação profissional e as decisões clínicas tomadas por estes profissionais. Para isso, realizamos um estudo transversal. Cirurgiões-dentistas $(n=276)$ de uma cidade de médio porte do sul do Brasil (Pelotas, RS) receberam um questionário contendo perguntas sobre informação sócio-demográfica, nível de especialização e ano de graduação. 
Adicionalmente, foram realizadas perguntas sobre o material de primeira escolha, técnicas e práticas clínicas relacionadas a clareamento de dentes vitais e não vitais. Os dados obtidos foram submetidos à análise descritiva e as possiveis associações entre variáveis foram avaliadas utilizando o teste Qui-Quadrado e teste Exato de Fisher $(p<0,05)$. A taxa de resposta foi de $68 \%$ (187). A técnica de clareamento caseiro supervisionada foi preferida $(78,1 \%)$ em detrimento da técnica em consultório $(21,9 \%)$. Os dentistas escolheram preferentemente o peróxido de carbamida (PC) a $10 \%$ para clareamento vital caseiro $(40,2 \%)$ e o peróxido de hidrogênio $(\mathrm{PH})>30 \%$ para o clareamento de dentes despolpados $(31,7 \%)$. A maioria dos dentistas que realizaram cursos de pós-graduação preferiram o clareamento caseiro $(p=0,003)$. Além disso, o clareamento caseiro foi mais indicado pelos dentistas mais jovens. Não foi encontrada relação entre as escolhas para clareamento de dentes despolpados e ano de graduação $(p=0,532)$ ou grau de formação $(p=0,083)$. 0 clareamento vital caseiro foi escolhido em detrimento das técnicas de consultório; CP a 10\% e HP $>30 \%$ foram os agentes de escolha para o tratamento de dentes vitais e não vitais escurecidos, respectivamente. 0 tempo de prática clínica e o nivel de especialização foram associados com as escolhas dos dentistas somente para clareamento de dentes vitais.

\section{References}

1. Demarco FF, Meireles SS, Masotti AS. Over-the-counter whitening agents: a concise review. Braz Oral Res 2009;23:64-70.

2. Joiner A. The bleaching of teeth: a review of the literature. J Dent 2006; 34:412-419.

3. Meireles SS, Fontes ST, Coimbra LA, Della Bona A, Demarco FF. Effectiveness of different carbamide peroxide concentrations used for tooth bleaching: an in vitro study. J Appl Oral Sci 2012;20:186-191.

4. Tay LY, Kose $C$, Herrera DR, Reis A, Loguercio AD. Long-term efficacy of in-office and at-home bleaching: a 2-year double-blind randomized clinical trial. Am J Dent 2012;25:199-204.

5. Meireles SS, Heckmann SS, Leida FL, dos Santos I da S, Della Bona A, Demarco FF. Efficacy and safety of $10 \%$ and $16 \%$ carbamide peroxide tooth-whitening gels: a randomized clinical trial. Oper Dent 2008;33:606-612.

6. Demarco FF, Freitas JM, Silva MP, Justino LM. Microleakage in endodontically treated teeth: influence of calcium hydroxide dressing following bleaching. Int Endod J 2001;34:495-500.

7. Vieira C, Silva-Sousa YT, Pessarello NM, Rached-Junior FA, SouzaGabriel AE. Effect of high-concentrated bleaching agents on the bond strength at dentin/resin interface and flexural strength of dentin. Braz Dent J 2012;23:28-35.

8. Lynch CD, McConnell RJ. Attitudes and use of rubber dam by Irish general dental practitioners. Int Endod J 2007;40:427-432.

9. Lynch CD, Ash PJ, Chadwick BL, Hannigan A. Evaluation of a U.K. community-based clinical teaching/outreach program by former dental students two and five years after graduation. J Dent Educ 2010;74:1146-1152.

10. Demarco FF, Baldissera RA, Madruga FC, Simoes RC, Correa MB, Lund RG, et al. Anterior composite restorations in clinical practice: findings from a survey with general dental practitioners. J Appl Oral Sci 2013 [Epub ahead of print. DOI: http://dx.doi.org/10.1590/1679775720130013]

11. Hatherell S, Lynch CD, Burke FM, Ericson D, Gilmour AS. Attitudes of final-year dental students to bleaching of vital and non-vital teeth in Cardiff, Cork, and Malmo. J Oral Rehabil 2011;38:263-269.

12. Soares DG, Ribeiro AP, Lima AF, Sacono NT, Hebling J, Costa CA. Effect of fluoride-treated enamel on indirect cytotoxicity of a 16\% carbamide peroxide bleaching gel to pulp cells. Braz Dent J 2013;24:121-127.

13. Marson FC, Sensi LG, Vieira LCC, Araújo E. Clinical evaluation of inoffice dental bleaching treatments with and without the use of lightactivation sources. Oper Dent 2008;33:11-18.

14. He LB, Shao MY, Tan K, Xu X, Li JY. The effects of light on bleaching and tooth sensitivity during in-office vital bleaching: a systematic review and meta-analysis. J Dent 2012;40:644-653.

15. Matis BA, Cochran MA, Wang G, Eckert GJ. A clinical evaluation of two in-office bleaching regimens with and without tray bleaching. Oper Dent 2009;34:142-149.

16. Hasson H, Ismail AI, Neiva G. Home-based chemically-induced whitening of teeth in adults. Cochrane Database of Syst Rev 2006; 18, CD006202.

17. American Dental Association (ADA) Consumer products with the ADA Seal of Acceptance. Retrieved online September 20, 2012 from: http:// www.ada.org/5266.aspx?category=Whitening+Products\%2c+Dentist+ Dispensed\%2fHome-Use.

18. Meireles SS, Santos IS, Bona AD, Demarco FF. A double-blind randomized clinical trial of two carbamide peroxide tooth bleaching agents: 2-year follow-up. J Dent 2010;38:956-963.

19. de la Peña VA, Ratón ML. Randomized clinical trial on the efficacy and safety of four professional at-home tooth whitening gels. Oper Dent 2013;17 [Epub ahead of print. DOI: http://dx.doi.org/10.2341/12402-C].

20. Lima FG, Rotta TA, Penso S, Meireles SS, Demarco FF. In vitro evaluation of the whitening effect of mouth rinses containing hydrogen peroxide. Braz Oral Res 2012;26:269-274.

21. Glockner $K_{1}$, Hulla $H$, Ebeleseder $K$, Städtler P. Five-year follow-up of internal bleaching. Braz Dent J 1999;10:105-110.

22. Sato $C$, Rodrigues FA, Garcia DM, Vidal CM, Pashley DH, Tjäderhane $L$, et al.. Tooth bleaching increases dentinal protease activity. J Dent Res 2013;92:187-192.

23. Valera $\mathrm{MC}$, Camargo $\mathrm{CH}$, Carvalho $\mathrm{CA}$, de Oliveira LD, Camargo $\mathrm{SE}$, Rodrigues CM. Effectiveness of carbamide peroxide and sodium perborate in non-vital discolored teeth. J Appl Oral Sci 2009;17:254261.

24. Buchalla W, Attin T. External bleaching therapy with activation by heat, light or laser - a systematic review. Dent Mater 2007;23:586-596.

25. McCaul LK, McHugh S, Saunders WP. The influence of specialty training and experience on decision making in endodontic diagnosis and treatment planning. Inter Endod J 2001;34:594-606.

Received December 19, 2012 Accepted August 28, 2013 